Luc Hens, Ph.D., Professor, Vlaamse Instelling voor Technologish Onderzoek, Boeretang, Belgium, Universidad de la Costa Calle, Barranquilla, Colombia,

Sumy State University, Sumy, Ukraine

Oleksandra Karintseva,

Ph.D., Associate Professor, Sumy State University,

Sumy, Ukraine

Mykola Kharchenko, Ph.D., Associate Professor, Sumy State University, Sumy, Ukraine

Oleksandr Matsenko, Ph.D., Associate Professor, Sumy State University,

Sumy, Ukraine

\title{
THE STATE'S STRUCTURAL POLICY INNOVATIONS INFLUENCED BY THE ECOLOGICAL TRANSFORMATIONS
}

The extension and legislative consolidation of the sustainable development conception in different countries of the world, including in Ukraine, define the necessity to form a new system, which will enable to provide the economic stability, social welfare and ecological balance in a balanced manner. It requires the development of the comprehensive strategy for the restructuring of the national economy. The optimization strategies restructuring policy of the economy in Ukraine with account for the ecological constituent should be based on the setting of the threedimensional problem regarding the game theory and on its complex solving through the iteration method. In order to reach a compromise, it is envisaged to search for the optimal restructuring policy for three subjects: state, population and economic entities, the behaviour strategy of which is formed on the basis of the quartile approach. The definition "value of game" - generalized effective indicator to assess the restructuring strategies efficiency (GDP, adjusted for the ecological factor), is proposed to be determined on the basis of the regressive analysis of its dependence on the integral indicators of subjects evaluation, calculated through bulk based on the average geometric mean of the normalized incoming indicators by the relative method. The suggested approach was approbated on the basis of time diapason 1999-2017, in view of maxi-maxi-max, mini-maxi-max, medium-maxi-max approaches. Calculations show that only maxi-maxi-max, mini-maxi-max, medium-maxi-max strategies enable to solve the above task in a compromise way since they simultaneously take into account the interests of the state, population and economic entities, providing the normal GDP, adjusted for the ecological factor. Directions for the introduction of the optimization strategies restructuring policy of the economy in Ukraine with account for the ecological constituent are proposed in the article.

Keywords: restructuring, strategies, optimization, national economy, ecological factor.

Introduction. The twentieth century is characterized by the qualitative transformation of basic principles regarding the functioning of industrially developed countries' national economies and of the 
world economy on the whole. In particular, the extension and legislative consolidation of the sustainable development conception in different countries of the world, including in Ukraine, define the necessity to form a new system, which will enable to provide the economic stability, social welfare and ecological balance in a balanced manner.

Modern ecological and economic situation in Ukraine points out the necessity to come to the stable ecologically balanced type of the economic development. Ecologization has to comprise all spheres of the public activity: industry, agriculture, science, social and legal spheres.

The innovations should facilitate such transition. These innovations relate not only to the technical decisions but also to the technological ones. They completely provide a progressive transformation of the state's structural policy. They result in a constant reproduction of new organizational decisions, standards, motivational tools. That is why it is urgent and significant to find the scientific approaches to determine possible ways for implementation of such innovative transformations in the social and economic development of the national economy, which will satisfy the principles of the stable balanced ecological development.

Problem setting. The economic aspects regarding the structural transformations in the development of the national economy are studied in works of the leading scientists in the world. The theory of the structural transformation is represented as a model, which is characterized by the endogenous and exogenous factors of influence (among which one may distinguish the level of education, technological development, access to foreign markets etc) on the economic growth and transformation process restriction in works of $\mathrm{H}$. Chenery and $\mathrm{A}$. Straut (Chenery, 1966).

J. Forrester and $\mathrm{D}$. Meadows form the model of the system dynamics regarding global development, which enables to predict the catastrophic consequences by way of the global problems aggravation such as the planetary ecological crisis, the natural resources exhausting, the industrial production decline and demographic crisis. They propose to follow so-called "zero growth" as a direction for structural changes in the economy (Meadows, 1972, 2006, Forrester, 2003).

Supranational theory of the structural transformations (F. Sharp, P. Schmidt, V. Strick) appears as a response for the political and economic globalization of the world and formation of the supranational units. According to this theory, they play a leading role in the management of the national economies' development. It provides transformation of the economic sectoral structures to the standards on a competitive basis (Streeck, 1985).

In D. North's work, the structural changes of the economy relate to the institutional reconstruction of the national economy fundamentals, based on the innovativeness of the state management. It will enable to form the potential for further economic development (North, 2000).

In works of J. Schumpeter, who founded the innovative theory of the economic development, a special place is given to the justifying of regularities in the cyclic renewal of the economic structure. (Schumpeter, 2008). The German scientist H. Mensch continues to investigate the scientific assumption of J. Schumpeter. He grounds the biggest susceptibility of the structural economic elements to the innovations during the depression periods (Mensch, 1979). The empiric confirmation of the above theoretical grounds is received in the work of M. Hirooka (Hirooka, 2006) through determination of the close correlation between "diffusion" and large cycles of M. D. Kondratyev, especially in the growth phase, where the innovative development reaches its top position. One more distinguishing scientific work in the study of the structural changes in the economy is a modern economic growth theory of the Nobel laureate $\mathrm{S}$. Kuznets, who proved that there were structural economic shifts in the economic development (Kuznets, 2005).

The influence of the ecological factors on the structural transformations regarding the social and economic development of the national economy is investigated in works of Khvestyk M.A. (2016), Maslak O.I. (2016), Melnyk L.G. (2015), Shkarupa O.V. (2016, 2017), Karintseva O.I. (2017), Kulyasov I.P. (2005). 
Melnyk L.G. studies a trialectical mechanism for the economic innovations implementation and proposes methods to evaluate the ecological constituent of the economic entities' activity in his works. (Melnyk, 2015).

Shkarupa O.V. mentions that the ecological modernization process of the national economy is based on the renewable ecologically oriented transformations in each social and economic system following the self-organization laws. It consists in the provision of its dynamic development on conditions that basic institutional forms regarding the functioning of the national economy will be provided (Shkarupa, 2016, 2017).

Kulyasov I. observes the ecological modernization as "a consciously organized process and social practice, which help improve the environmental situation and human health, and are implemented through the relevant social institutions and their cooperation" (Kulyasov, 2005).

However the problem regarding the state's restructuring policy optimization considering the ecological factor and economic growth priorities have not been enough studied yet.

The aim of this research is to develop the scientific and methodical approach to the optimization of the state's structural policy considering the ecological factor and the economic growth priorities

The results of the research. Turning directly to the practical implementation of the proposed scientific and methodical approach to form the optimization strategies restructuring policy of the economy in Ukraine with account for the ecological constituent, we can note that it should be based on the setting of the threedimensional problem regarding the game theory and on its complex solving through the iteration method. In order to reach a compromise, it is envisaged to search for the optimal restructuring policy for three subjects: state, population and economic entities, the behaviour strategy of which is formed on the basis of the quartile approach. The "value of game" - generalized effective indicator to assess the restructuring strategies efficiency (GDP, adjusted for the ecological factor), is proposed to be determined on the basis of the regressive analysis of its dependence on the integral indicators of subjects evaluation, calculated through bulk based on the average geometric mean of the normalized incoming indicators by the relative method. The suggested approach was approbated on the basis of time diapason 1999-2017, in view of maxi-maxi-max, mini-maxi-max, medium-maxi-max approaches.

At the first stage of the proposed scientific and methodical approach implementation, the incoming statistic data set for the quantitative evaluation and ex-post prediction of the restructuring policy optimization strategies regarding the economy in Ukraine taking into account the ecological factor in the context of such subjects as a state, population and economic entities are formed.

Thus, we will carry out a quantitative description of each subject in the restructuring process of the national economy in Ukraine:

1) to evaluate the state one proposes to choose: cost for reforming (\% of GDP), tax revenues (\% of GDP), number of public servants (persons);

2) to evaluate the population one proposes to choose: birth rate (per 1000 people), death rate (per 1000 people), unemployment (\% of the total number of labour power), total resources on average per month per one household, the expected duration of life at birth;

3) to evaluate economic entities one proposes to choose: direct foreign investment, net inflows (\% of GDP), the new registered business (units), total tax rate (\% of the commercial benefit), quantity of the economic entities, net profit, loss of large and medium-sized enterprises ( $\mathrm{mln} \cup A H)$.

Thus, GDP, adjusted for such indicators of the ecological factor as flexible renewable energy sources and wastes (\% of the total energy), $\mathrm{CO}_{2}$ emissions (metric tons per capita) is proposed to be an effective indicator of the strategies efficiency assessment.

Within the framework of this stage, there is a necessity to predict the absence of time series levels. It is proposed to be carried out on the basis of the data extrapolation and interpolation via the average growth rate method. It will enable to increase the studied period diapason regarding the restructuring optimization 
policy of economy in Ukraine considering the ecological factor and to extend the possible alternative strategies to make managerial decisions within this issue.

Besides, there is a necessity to introduce symbols for further calculations: to compare indicators, to form the integral indicators for evaluation of the state, population and economic entities on the whole, and also to use the game theory tools with the purpose to form optimal strategies regarding restructuring process of the economy in Ukraine.

The second stage includes the formation of the generalized integral indicator to assess the strategies regarding restructuring policy optimization of the economy' in Ukraine in the context of the state, and the econometric models' construction of the absolute incoming indicators dependence on the generalized integral indicator. Since this stage is complex and provides an implementation of some consequent steps, we will observe this calculation process in more detail:

2.1. To compare the incoming indicators through the implementation of the relative normalization considering their character of the influence on the effective indicator (stimulators, destimulators). Since all indicators are stimulators for the selected group of indices, i.e. they increase the effective indicator value by growing, the formula for calculations considering symbols, introduced at the first stage, may be written in the following way:

$$
\tilde{d}_{i t}=\frac{d_{i t}}{\max _{t} d_{i t}}
$$

where $\tilde{d}_{i t}$ - normalized value of $\mathrm{i}$-th indicator $(\mathrm{i}=1,2,3)$ regarding the assessment of restructuring policy optimization strategies of the economy in Ukraine in the context of the state during the t-year; $d_{i t}$-absolute incoming value of $i$-th indicator $(i=1,2,3)$ regarding the assessment of restructuring policy optimization strategies of the economy in Ukraine in the context of the state during the t-year; $\max _{t} d_{i t}$ - maximum absolute value of $\mathrm{i}$-th indicator during the whole studied period.

2.2.Calculation of the generalized integral indicator to assess the restructuring policy optimization strategies of the economy in Ukraine in the context of the state through the normalized bulk indicators based on the average geometric mean. Implementation of three normalized indicators as a bulk mechanism based on the average geometric mean is caused by the fact that we will not obtain zero values, which will distort the trend, owing to the relative normalization.

$$
D_{t}=\sqrt[3]{\prod_{i=1}^{3} \tilde{d}_{i t}}=\sqrt[3]{\prod_{i=1}^{3} \frac{d_{i t}}{\max _{t} d_{i t}}}
$$

where $D_{t}$ - generalized indicator to assess the restructuring policy optimization strategies of the economy in Ukraine in the context of the state per t-year.

2.3 Establishment of the correspondence between absolute values to assess the restructuring policy optimization strategies of the economy in Ukraine in the context of state and the calculated values of the generalized integral indicator, based on the formation of paired linear and nonlinear regression equations. The previous investigation of the statistic data regarding the possible dependence of three indicators for the state's assessment on the integral generalized indicator demonstrates the linear dependence, which may be described through the following function:

$$
d_{i t}=a_{0 i}+a_{1 i} \cdot D_{t}
$$

where $a_{0 i}$ - constant, regression equation parameter, which denotes the average value of the i-th indicator to assess the restructuring policy optimization strategies of the economy in Ukraine in view of the state at zero integral 
indicator; $a_{1 i}$ - constant, regression equation parameter, which denotes how i-th indicator to assess the restructuring policy optimization strategies of the economy in Ukraine in view of the state is changed with an increase (decrease) of the integral indicator by 1 (unit fractions).

Implementation of this step will provide the breaking down of the integral indicator optimal value into three absolute values of the indicators to assess restructuring policy optimization strategies of the economy in Ukraine in view of the state. It will enable comprehensively to describe the chosen strategy, based not on the artificially introduced integral indicators, but on the real indices.

The third stage. Formation of the generalized integral indicator to assess the restructuring policy optimization strategies of the economy in Ukraine in view of the population; construction of the econometric models of absolute incoming indicators dependencies on the generalized integral indicator. This stage is carried out in the same way as in the previous stage.

The fourth stage accumulates calculations of the integral indicator to assess the restructuring policy optimization strategies of the economy in Ukraine in view of the economic entities with further construction of regression equations of absolute incoming indicators dependencies on the generalized integral indicator. This stage is carried out in the same way as in the previous 2 and 3 stages.

The fifth stage of the scientific and methodical approach implementation is to calculate the generalized effective indicator to assess the efficiency of the restructuring policy optimization strategies of the economy in Ukraine considering the ecological factor. There is a necessity to define the ecological adjustment index with further corrections of GDP on the above mentioned ecological index in dynamics at this stage. So, in order to calculate the ecological adjustment index, at first we will normalize indicators of ecological factor assessment since the indicator of flexible renewable sources and wastes ( $\%$ of the total energy) is a stimulator, and $\mathrm{CO}_{2}$ emissions (metric tons per capita) - a destimulator. The relative normalization is proposed to be used:

$$
\begin{gathered}
\tilde{e}_{1 t}=\frac{e_{1 t}}{\max _{t} e_{1 t}} \\
\tilde{e}_{2 t}=\frac{\min _{t} e_{2 t}}{e_{2 t}}
\end{gathered}
$$

where $\tilde{e}_{i t}$ - normalized value of indicator $\mathrm{i}$-th ( $\left.\mathrm{i}=1,2\right)$ of the ecological constituent assessment during t-year; $e_{i t}$ - absolute incoming value of indicator $\mathrm{i}$-th $(\mathrm{i}=1,2)$ of the ecological constituent assessment during t-year; $\max _{t} e_{i t}-$ maximum absolute value of indicator $i$-th of the ecological constituent assessment during the whole studied period; $\min _{t} e_{i t}$ - minimum absolute value of indicator $\mathrm{i}$-th of the ecological constituent assessment during the whole studied period;

The next step in this stage is to calculate the ecological adjustment index. It is proposed to be calculated on the basis of the average geometric mean regarding the normalized values of constituents with further corrections of each time series on average value:

$$
\widetilde{E K}_{t}=\sqrt{\prod_{i=1}^{2} \tilde{e}_{i t}}=\sqrt{\frac{e_{1 t}}{\max _{t} e_{1 t}} \cdot \frac{\min _{t} e_{2 t}}{e_{2 t}}} \Rightarrow E K_{t}=\frac{\widetilde{E K}_{t}}{\sum_{t=1}^{T} \widetilde{E K}_{t} / T}=\frac{\sqrt{\frac{e_{1 t} \cdot \min _{t} e_{2 t}}{\max _{1 t} \cdot \frac{e_{2 t}}{e_{2}}}}}{\sum_{t=1}^{T} \sqrt{\frac{e_{1 t} \cdot \min _{t} e_{2 t} e_{1 t}}{\max _{2 t}}} / T}
$$

where $E K_{t}$ - ecological adjustment index during t-year; $\widetilde{E K}_{t}$ - intermediate calculations during t-year.

Thus, having calculated the ecological adjustment index, we can perform the last step in this stage to calculate generalized effective indicator to assess the efficiency of the restructuring policy optimization 
strategies of the economy in Ukraine considering the ecological factor that is GDP, adjusted for the ecological factor:

$$
G D P_{t}^{*}=\frac{G D P_{t}}{E K_{t}}=\frac{G D P_{t} \cdot \sum_{t=1}^{T} \sqrt{\frac{e_{1 t}}{\max _{t} e_{1 t}} \cdot \frac{\min _{t} e_{2 t}}{e_{2 t}}} / T}{\sqrt{\frac{e_{1 t}}{\max _{t} e_{1 t}} \cdot \frac{\min _{t} e_{2 t}}{e_{2 t}}}}
$$

$G D P_{t}^{*}-\mathrm{GDP}$, adjusted for the ecological constituent during t-year.

Reasonability to use formula (7), i.e. division of GDP by ecological adjustment index, caused by this index character as destimulator, i.e. such an adjustment index, which has to reduce the GDP level through increasing of its value and vice versa. The sixth stage includes setting and solving of tasks to form the restructuring policy optimization strategies of the economy in Ukraine considering the ecological factor as the game theory tasks. In order to form this stage, it is necessary to:

1. Define participants of the conflict situation, the compromise reaching of which will enable to define the optimal policy of the state, population and economic entities restructuring, each of which pursues own aims, depending on other subjects' behavior.

2. Define the strategies regarding the behavior of the state, population and economic entities: S1 a situation, when we try to implement the planned actions of policy, but they do not work out in a proper manner; S2 - a situation, where the planned actions of the policy work out in a proper manner; S3 - a situation, when innovative approaches to the restructuring of the economy will be implemented.

3. Describe the identified strategies quantitatively. It is proposed to carry out on the basis of the absolute and integral indicators of the state, population and economic entities, demonstrated in the above stages.

4. Put the values intervals of the integral indicators regarding features of the state, population and economic entities to suit the introduced strategies of the participants' actions: S1 - value within the first and the second quartiles of the integral indicator's possible values in the range from minimum to maximum, S2 - values within the second and third quartiles, S3 - within the fourth and fifth quartiles.

5. Construct the payment matrix of this "game" (conflict situation to look for the restructuring optimization policy of economy in Ukraine considering the ecological factor), which requires definition "(value of game)" - a generalized effective indicator to assess the strategies efficiency - GDP, adjusted for the ecological factor.

6. Define dependence "value of game" (GDP considering the ecological factor) on the integral indicators of participants' assessment in the conflict situation (state, population, economic entities). It is proposed to carry out on the basis of the regression analysis.

7. Solve optimization task by the iteration method, that will enable to form an analytical set of tools to make relevant decisions regarding the restructuring policy of the economy in Ukraine considering the ecological factor.

The detailed analysis of iterations results regarding the restructuring policy optimization of the economy in Ukraine considering the ecological factor enables to distinguish strategies of the greatest interest in terms of finding a compromise solution for three interested sides, and therefore providing the appropriate level of the efficiency indicator. Such strategies are: the strategy, which provides maximum possible value of GDP, adjusted for the ecological factor (Table 1), maxi-mini-max (Table 2), maxi-maximax (Table 3), maxi-maxi-medium (Table 4), mini-maxi-medium (Table 5), mini-maxi-max (Table 6), medium-maxi-medium (Table 7), medium-maxi-max (Table 8). The detailed analysis of the first two above strategies (Table 1, Table 2) enables to confirm that despite the fact that approaches to the restructuring policy optimization of the economy in Ukraine considering the ecological factor let to provide the maximum 
L. Hens, O. Karintseva, M. Kharchenko, O. Matsenko. The State's Structural Policy Innovations Influenced by the Ecological Transformations

possible or very close to it GDP levels, implementation of these strategies makes to neglect the interests of the population.

Table 1 - Results of the strategy introduction, which provides the maximum possible value of GDP, adjusted for the ecological factor (authors' calculations)

\begin{tabular}{|c|c|c|c|}
\hline 0.9054 & 0.4362 & 0.7718 & $3.4993 \mathrm{E}+11$ \\
\hline $\mathrm{D}$ & $\mathrm{N}$ & SG & $\mathrm{GDP}^{*}$ \\
\hline $\mathrm{D} 1$ & 40.2838 & Costs for reforming (\% Bof GDP) & \\
\hline $\mathrm{D} 2$ & 18.7698 & Tax revenues ( $\%$ of GDP) & \\
\hline D3 & 380425.3537 & Number of public servants (persons) & \\
\hline $\mathrm{N} 1$ & 7.7418 & Birth rate (per 1000 people) & \\
\hline N2 & 14,5909 & Death rate (per 1000 people) & \\
\hline N3 & 12,0061 & Unemployment ( $\%$ of the total number of labour power) & \\
\hline N4 & 281.3859 & Total resources on average per month per one househol & \\
\hline N5 & 67.2800 & The expected duration of life at birth (years) & \\
\hline SG1 & 5.3574 & Direct foreign investment, net inflow (\% of GDP) & \\
\hline SG2 & 33858.1686 & A new registered business (units) & \\
\hline SG3 & 56.9544 & Total tax rate (\% Bof the commercial benefit) & \\
\hline SG4 & 2457883.5655 & The quantity of the economic entities, (units) & \\
\hline SG5 & 108491.8659 & Net profit, loss of the large and medium-sized enterprise & $\mathrm{UAH})$ \\
\hline
\end{tabular}

Table 2 - Results of maxi-mini-max strategy introduction regarding restructuring policy optimization of the economy in Ukraine considering the ecological factor (authors' calculations)

\begin{tabular}{|c|c|c|}
\hline MAX & MIN & MAX \\
\hline 0.92552 & 0.43616 & $3.4993 \mathrm{E}+11$ \\
\hline $\mathrm{D}$ & $\mathrm{N}$ & $\mathrm{GDP}^{*}$ \\
\hline D1 & 41.3974 & Costs for reforming (\% Bof GDP) \\
\hline $\mathrm{D} 2$ & 19.2600 & Tax revenues (\% of GDP) \\
\hline D3 & 384959.2691 & Number of public servants (persons) \\
\hline N1 & 7.7418 & Birth rate (per 1000 people) \\
\hline N2 & 14.5909 & Death rate (per 1000 people) \\
\hline N3 & 120061 & Unemployment ( $\%$ of the total number of labour power) \\
\hline N4 & 281.3859 & Total resources on average per month per one household, UAH \\
\hline N5 & 67.2800 & The expected duration of life at birth (years) \\
\hline SG1 & 5.3574 & Direct foreign investment, net inflow (\% of GDP) \\
\hline SG2 & 33858.1686 & A new registered business (units) \\
\hline SG3 & 56.9544 & Total tax rate (\% Bof the commercial benefit) \\
\hline SG4 & 2457883.5655 & The quantity of the economic entities, (units) \\
\hline SG5 & 108491.8659 & Net profit, loss of large and medium-sized enterprises (mln UAH) \\
\hline
\end{tabular}

It is affirmed by the very low value of total resources on average per month per one household, UAH at the level 281.39 $\mathrm{UAH}$, that we find unacceptable. That is why the mentioned strategies must be refused and we have to look for the compromise strategies.

Table 3 - Results of maxi-maxi-max strategy introduction regarding restructuring policy optimization of the economy in Ukraine considering the ecological factor (authors' calculations)

\begin{tabular}{|c|c|c|c|}
\hline MAX & MAX & MAX & \\
\hline & 2 & 3 & \\
\hline 0.9255 & 0.9272 & 0.7718 & $9.4482 \mathrm{E}+10$ \\
\hline $\mathrm{D}$ & $\mathrm{N}$ & SG & GDP $^{*}$ \\
\hline D1 & 41.3974 & Costs for reforming (\% Bof GDP) & \\
\hline D2 & 19.2600 & Tax revenues (\% of GDP) & \\
\hline
\end{tabular}




\begin{tabular}{|l|r|l|}
\hline \multicolumn{1}{|c|}{$\mathbf{1}$} & \multicolumn{1}{|c|}{$\mathbf{2}$} & \multicolumn{1}{|c|}{$\mathbf{3}$} \\
\hline D3 & 384959.2691 & Number of public servants (persons) \\
\hline N1 & 11.6539 & Birth rate (per 1000 people) \\
\hline N2 & 14.3464 & Death rate (per 1000 people) \\
\hline N3 & 9.0551 & Unemployment (\% of the total number of labour power) \\
\hline N4 & 7224.8940 & Total resources on average per month per one household, UAH \\
\hline N5 & 71,1461 & The expected duration of life at birth (years) \\
\hline SG1 & 5.3574 & Direct foreign investment, net inflow (\% of GDP) \\
\hline SG2 & 33858.1686 & A new registered business (units) \\
\hline SG3 & 56.9544 & Total tax rate (\% Bof the commercial benefit) \\
\hline SG4 & 2457883.5655 & The quantity of the economic entities, (units) \\
\hline SG5 & 108491.8659 & Net profit, loss of large and medium-sized enterprises (mln UAH) \\
\hline
\end{tabular}

The negative net profit of the large and medium-sized enterprises has been obtained (Table 4).

Table 4 - Results of maxi-maxi-medium strategy introduction regarding restructuring policy optimization of the economy in Ukraine considering the ecological factor (authors' calculations)

\begin{tabular}{|c|c|c|}
\hline MAX & MAX & SR \\
\hline 0.9255 & 0.9272 & $7.9064 \mathrm{E}+10$ \\
\hline $\mathrm{D}$ & $\mathrm{N}$ & $\mathrm{GDP}^{*}$ \\
\hline D1 & 41.3974 & Costs for reforming (\% Bof GDP) \\
\hline D2 & 19.2600 & Tax revenues ( $\%$ of GDP) \\
\hline D3 & 384959.2691 & Number of public servants (persons) \\
\hline N1 & 11.6539 & Birth rate (per 1000 people) \\
\hline N2 & 14.3464 & Death rate (per 1000 people) \\
\hline N3 & 9.0551 & Unemployment (\% of the total number of labour power) \\
\hline N4 & 7224.8940 & Total resources on average per month per one household, UAH \\
\hline N5 & 71.1461 & The expected duration of life at birth (years) \\
\hline SG1 & 4.0780 & Direct foreign investment, net inflow (\% of GDP) \\
\hline SG2 & 29993.9364 & A new registered business (units) \\
\hline SG3 & 56.7526 & Total tax rate ( $\%$ Bof the commercial benefit) \\
\hline SG4 & 2107473.1864 & The quantity of the economic entities, (units) \\
\hline SG5 & -11673.8412 & Net profit, loss of large and medium-sized enterprises (mln UAH) \\
\hline
\end{tabular}

Observing the maxi-maxi-medium (Table 4), mini-maxi-medium (Table 5), medium-maxi-medium (Table 7) strategies, it is necessary to mention that despite the possibility to provide the sufficient level of GDP, the above approaches foresee the economic entities' unprofitable functioning, since the net profit, loss of the large and medium-sized enterprises is negative. Taking into account the mentioned drawback we do not have to consider maxi-maxi-medium (Table 4), mini-maxi-medium (Table 5), medium-maximedium (Table 7) strategies. The negative net profit of the large and medium-sized enterprises has been obtained (Table 5).

Table 5 - Results of mini-maxi-medium strategy introduction regarding restructuring policy optimization of the economy in Ukraine considering the ecological factor (authors' calculations)

\begin{tabular}{|c|c|c|c|}
\hline MIN & MAX & SR & \\
\hline 0.6550 & 0.9272 & 0.6274 & $1.1587 \mathrm{E}+10$ \\
\hline $\mathrm{D}$ & $\mathrm{N}$ & SG & $\mathrm{GDP}^{*}$ \\
\hline $\mathrm{D} 1$ & 26.4323 & Costs for reforming (\% Bof GDP) & \\
\hline $\mathrm{D} 2$ & 12.6713 & Tax revenues ( $\%$ of GDP) & \\
\hline D3 & 324030.0418 & Number of public servants (persons) & \\
\hline $\mathrm{N} 1$ & 11.6539 & Birth rate (per 1000 people) & \\
\hline N2 & 14.3464 & Death rate (per 1000 people) & \\
\hline
\end{tabular}


L. Hens, O. Karintseva, M. Kharchenko, O. Matsenko. The State's Structural Policy Innovations Influenced by the Ecological Transformations

Table 5

\begin{tabular}{|l|r|l|}
\hline N3 & 9.0551 & Unemployment (\% of the total number of labour power) \\
\hline N4 & 7224.8940 & Total resources on average per month per one household, UAH \\
\hline N5 & 71.1461 & The expected duration of life at birth (years) \\
\hline SG1 & 4.0780 & Direct foreign investment, net inflow (\% of GDP) \\
\hline SG2 & 29993.9364 & A new registered business (units) \\
\hline SG3 & 56.7526 & Total tax rate (\% Bof the commercial benefit) \\
\hline SG4 & 2107473.1864 & The quantity of the economic entities, (units) \\
\hline SG5 & -11673.8412 & Net profit, loss of large and medium-sized enterprises (mIn UAH) \\
\hline
\end{tabular}

Table 6 - Results of mini-maxi-max strategy introduction regarding restructuring policy optimization of the economy in Ukraine considering the ecological factor (authors' calculations)

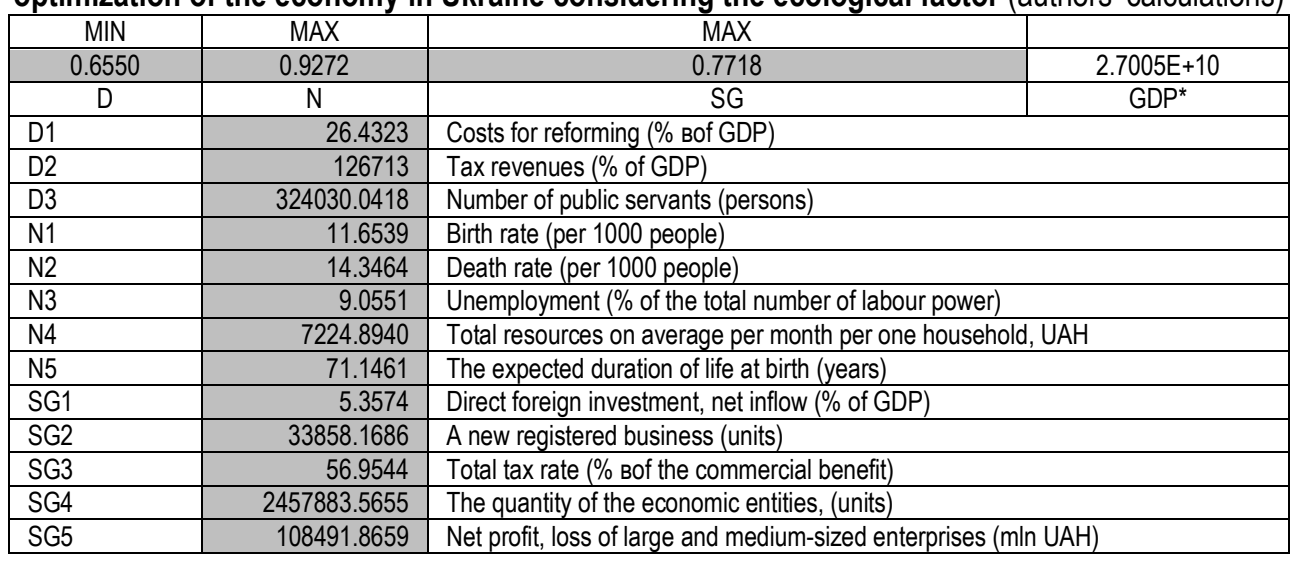

Thus, only maxi-maxi-max (Table 3), mini-maxi-max (Table 6), medium-maxi-max (Table 8) strategies enable to solve the problem of the restructuring policy optimization of the economy in Ukraine considering the ecological constituent, since interests of the state, population and economic entities are simultaneously taken into account, providing the normal level of GDP, adjusted for the ecological factor.

Table 7 - Results of medium-maxi-medium strategy introduction regarding restructuring policy optimization of the economy in Ukraine considering the ecological factor (authors' calculations)

\begin{tabular}{|c|c|c|c|}
\hline SR & MAX & SR & \\
\hline 0.8095 & 0.9272 & 0.6274 & $5.013 \mathrm{E}+10$ \\
\hline $\mathrm{D}$ & $\mathrm{N}$ & SG & $\mathrm{GDP}^{*}$ \\
\hline D1 & 34.9804 & Costs for reforming (\% Bof GDP) & \\
\hline $\mathrm{D} 2$ & 16.4348 & Tax revenues $(\%$ of GDP) & \\
\hline D3 & 358832.9708 & Number of public servants (persons) & \\
\hline $\mathrm{N} 1$ & 11.6539 & Birth rate (per 1000 people) & \\
\hline N2 & 14.3464 & Death rate (per 1000 people) & \\
\hline N3 & 9.0551 & Unemployment (\% of the total number of labour power) & \\
\hline N4 & 7224.8940 & Total resources on average per month per one householc & $\mathrm{d}, \mathrm{UAH}$ \\
\hline N5 & 71.1461 & The expected duration of life at birth (years) & \\
\hline SG1 & 4.0780 & Direct foreign investment, net inflow (\% of GDP) & \\
\hline SG2 & 29993.9364 & A new registered business (units) & \\
\hline SG3 & 56.7526 & Total tax rate (\% Bof the commercial benefit) & \\
\hline SG4 & 2107473.1864 & The quantity of the economic entities, (units) & \\
\hline SG5 & -11673.8412 & Net profit, loss of large and medium-sized enterprises (ml & $\ln \mathrm{UAH})$ \\
\hline
\end{tabular}


Table 8 - Results of medium-maxi-max strategy introduction regarding restructuring policy optimization of the economy in Ukraine considering the ecological factor (authors' calculations)

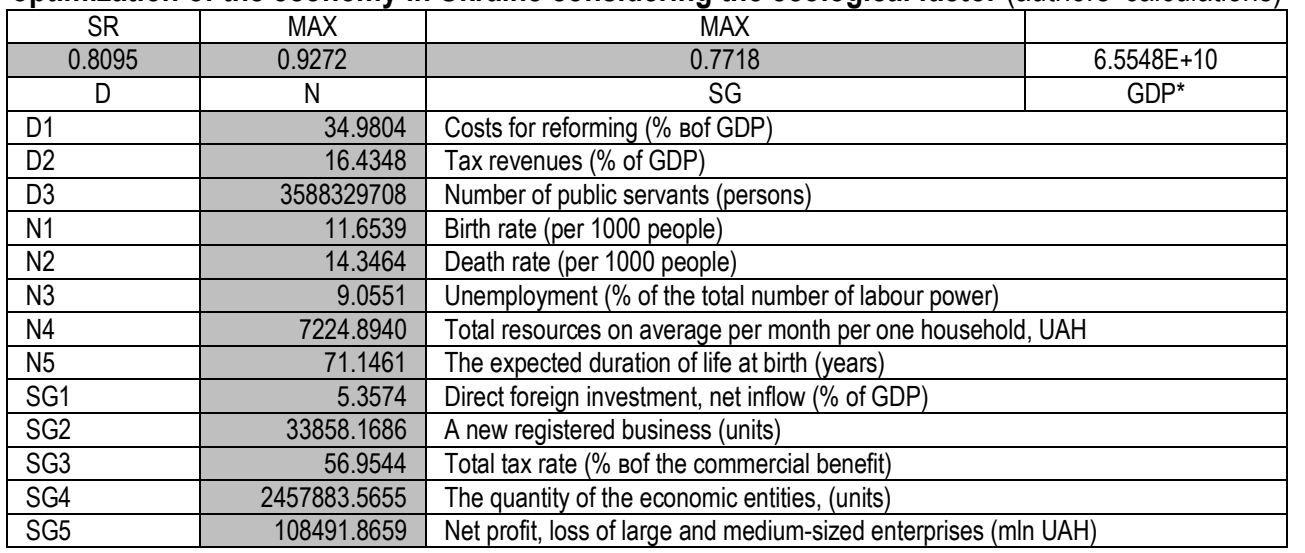

Conclusions. Thus, given the necessity to move to the stable ecologically balanced type of the economic development (Shkarupa, 2016, 2017; Karintseva, 2017; Kulyasov, 2005), the strategies regarding the restructuring of the national economy have to focus on:

- ecological restructuring and ecological modernization of production, that foresees a change of the sectoral structure through demand reduction of goods from the polluting industries or through enterprises' modernization - consumers of such goods;

- development and implementation of the eco-technologies, particularly, wider use of waste utilization technologies, resources recycling after their processing, recultivation of the disturbed lands;

- assisting the development of informational and telecommunication technologies and electronics; space and aviation, chemical, industrial, energy-saving, new transport technologies, the production of new goods and services;

- introduction of the environmental management systems at the industrial enterprises, that is a modern mechanism to manage the environmental activity, the functioning of which assists the improving of the enterprises' ecological indicators and reducing of the ecological risks and costs, as the foreign experience shows;

- formation of the ecological requirements to develop new ones, the ecological control implementation of the existing technologies into practice in accordance with modern ecological and economic norms and standards, that will assist increasing of the enterprises' innovative activity.

Summarizing the study of the theoretical bases for the restructuring of the economy, we can point out the necessity to transform views on this concept and on its main features. The meaningful aspects regarding the restructuring of the economy have to be revealed from the perspective of the stable ecologically balanced development, i.e. consideration of both economic-social and ecological grounds. The structure of the economy is an indicator of its stability, and an indicator to provide the national economic security in general.

Thus, the country's effective economic development depends not only on the resource provision, relationships quality between subjects of the economic relations, institutional space, innovations implementation level but also on the processes in the environment. 
L. Hens, O. Karintseva, M. Kharchenko, O. Matsenko. The State's Structural Policy Innovations Influenced by the Ecological Transformations 195

Bortis, H. (2000) Some considerations on structure and change. Structural Change and Economic Dynamics, No. 1-2, pp. 185-

Chenery, H., Strout, A.M. (1966) Foreign assistance and economic development. American Economic Review, Vol. 56(4), pp. $679-733$

Costanza, R., Folke, C. (1994) Ecological Economics and Sustainable Development. Paper prepared for the international

Experts Meeting for the Operationalization of the Economics of Sustainability. Manila, Philippines. July 28-30.

Forrester, J. (2003) World Dynamics. Moscow: AST (in Rus)

Herrendorf, B. (2013) Growth and Structural Transformation. NBER Working Paper, No. 18996, 114 p.

Hirooka, M. (2006) Innovation Dynamysm and Economic Growth. A Nonlinear Perspective. Edward Elgar, Cheltenham, UK and Northampton, MA, USA

Karintseva, O. I. (2017) Economic restructuring in Ukraine in view of destructive effect of enterprises on environment. International Journal of Ecological Economics and Statistics, Issue 4, Vol. 38, pp. 1-11.

Kaufmann, D., Kraay, A., Mastruzzi, M. (2010) The Worldwide Governance Indicators: Methodology and Analytical Issues. World Bank Policy Research Working Paper, No. 5430. URL : https://ssrn.com/abstract=1682130.

Khvesyk, M.A. (Ed.). (2016) Ecological modernization in the system of natural-technogenic and ecological safety. Kyiv: PI IEESD of the NAS of Ukraine (in Ukr).

Kulyasov, I. P. (2005) Environmental modernization: theoretical aspects. Sociology and Social Anthropology, №3, pp. 100-113 (in Rus).

Kuznets, S. (2005) Modern Economic Growth: results of research and reflection. Moscow: Sovremennaya ekonomika i pravo (in Rus).

Maslak, O.I. (Ed.). (2016) Sustainable development: strategic vectors, innovation-oriented ensuring systems in the context of Ukraine's European integration policy. Kremenchuk : PP Shcherbatykh O. V. (in Ukr).

Meadows, D.H.; Randers, J.; Meadows, D.L. (2006) Limits to growth. The 30-year update. London: Sterling, VA.

Meadows, D.H.; Randers, J.; Meadows, D.L.; Behrens, W. (1972) The Limits to Growth: A Report for the Club of Rome's Project on the Predicament of Mankind. New York: Universe Books.

Melnyk, L.G. (2015) Ecological and economic features of "spaceship Earth", or Horizons of the third Industrial Revolution and "Green" Economy. Marketing and management of innovations, №: 4, pp. 233-244 (in Ukr).

Mensch, G. (1979) Stalemate in Technology - Innovations Overcame the Depression. NY : Ballinger Publishing Company.

Mykhailova, L.I. (2017) State regulation of the modernization of the national economy in the context of stimulating the innovation development of Ukraine. Visnyk KhNAU, № 4, pp.56-68 (in Ukr).

North, D. (2000) Institutions, Institutional Change and Economic Performance. Kyiv: Osnovy. (in Ukr.)

Schumpeter, J.A. [1911] (2008) The Theory of Economic Development: An Inquiry into Profits, Capital, Credit, Interest and the

Business Cycle, translated from the German by Redvers Opie, New Brunswick (U.S.A) and London (U.K.): Transaction Publishers. Shkarupa, O.V., Karintseva, O.I., Shkarupa, I.S. (2016) Innovation Potential of Ecological Modernization for Green Growth of Economics: A Case Study. International Journal of Ecology \& Development, Vol. 31, No. 1, pp. 73-82.

Shkarupa, O.V., Kharchenko, M.O. (2017) Integrated Assessment of Environmental Costs of National Economy: A Case Study. International Journal of Ecological Economics \& Statistics, No. 3, pp. 43-50.

Streeck, Wolfgang/Philippe C. Schmitter (eds.). (1985) Private Interest Government: Beyond Market and State. London: Sage Thakur, S. (2011) Fundamental Economic Structure and Structural Change in Regional Economies: A Methodological Approach. Région et Développement, No. 33, pp. 9-38.

Л. Генс, к.е.н., професор, Фламандський інститут технологічних досліджень (Мол, Бельгія); Університет де ла Коста Калле (Барранкілья, Колумбія); Сумський державний університет (Суми, Україна);

O.І. Карінцева, к.е.н., доцент, Сумьский державний університет (Суми, Україна)

M.О. Харченко, к.е.н., доцент, Сумьский державний університет (Суми, Україна);

О.М. Маценко, к.е.н., доцент, Сумьский державний університет (Суми, Україна)

Інновації у структурній політиці держави під впливом екологічних транссформацій

Поширення та законодавче закріплення концепиії сталого розвитку в різних країнах світу, у тому числі в Україні, обумовлює потребу у формуванні нової системи, яка б збалансовано дозволила забезпечити економічну стабільність, соціальний добробут та екологічну рівновагу. Це потребує розробки комплексної стратегії реструктуризаціі національної економіки. Стратегії оптимізації політики реструктуризації економіки України з урахуванням екологічної складової повинні грунтуватись на постановці трьохмірної задачі теорії ігор та її комплексного вирішення методом ітерацій. Знаходження компромісу передбачає пошук оптимальної політики реструктуризації для трьох суб'єктів: держави, населення та суб'єктів господарювання, стратегії поведінки яких формалізовано на основі квартільного підходу. Визначення «ціни гри» - узагальнюючого результативного показника оцінювання есфективності стратегій реструктуризації (ВВП, скоригованого на екологічний чинник), запропоновано здійснювати на основі регресійного аналізу його залежності від інтегральних показників, обчислених иляхом згортки на основі середньої геометричної простої нормалізованих відносним методом вхідних показників. Запропонований підхід апробовано на основі часового діапазону 
1999-2017 рр., в розрізі максі-максі-максного, міні-максі-максного, середньо-максі-максного підходів. Розрахунки показали, що компромісно вирішити зазначену задачу оптимізації дозволяють лише максі-максі-максна, міні-максі-максна, середньо-максі-максна стратегії, оскільки одночасно враховують інтереси держави, населення, суб'єктів господарювання, забезпечуючи нормальний рівень ВВП, скоригованого на екологічний чинник. Запропоновано напрямки впровадження стратегій оптимізації політики реструктуризації економіки України з урахуванням екологічної складової. Ключові слова: реструктуризація, стратегії, оптимізація, національна економіка, екологічний фактор. 